\title{
Pengaruh Akuntabilitas Pengelolaan Keuangan Alokasi Dana Desa, Kebijakan Desa Dan Kelembagaan Desa Terhadap Kesejahteraan Masyarakat Pada Nagari Sungai Tanang Kecamatan Banuhampu Kabupaten Agam
}

\author{
Lasmi Yupita ${ }^{1}$, Verni Juita ${ }^{2}$ \\ ${ }^{1,2}$ Fakultas Ekonomi Pascasarjana Akuntansi, Universitas Andalas, Indonesia \\ Correspondence email: lasmiyupitaunand@gmail.com
}

\begin{abstract}
This research was conducted on the community in Nagari Sungai Tanang District of Banuhampu Agam Regency. The purpose of this study was to examine the effect of accountability on financial management of village fund allocations, village policies and village institutions on community welfare. This type of research is quantitative penenlitian. The object of this research is Nagari Sungai Tanang. Sampling method used is stratified random sampling and data is processed by multiple linear regression analysis, validity test, realibility and hypothesis testing with $F$ test and t test. The result of the research with the t-test of accountability management of Village Fund Allocation (ADD) is 0,034 <0,05 so it shows that accountability of Village Fund Allocation (ADD) influence posistif to welfare of society, while tsign of village policy equal to 0,000 $<0,05$ so indicate that policy villages have a positive effect on the welfare of the community, and the institutional tsign of the village with the amount of 0.001 $<0.05$ indicating that the village institutions have a positive effect on the welfare of the community.
\end{abstract}

Keywords: Village Fund Allocation; village policy; village institution; community welfare.

\section{Pendahuluan}

Tujuan utama dari pembangunan sebuah negara adalah untuk mensejahterakan masyarakat, sama seperti Negara Indonesia. Pemerintah Indonesia terus mengupayakan melakukan pembangunan di setiap daerah-daerah baik kota maupun desa, namun dalam pelaksanaan pembangunan ini pemerintah sering menghadapi permasalahan seperti adanya kesenjangan antara pembangunan desa dan kota yang diakibatkan oleh keadaan ekonomi masyarakat Indonesia yang tidak merata, untuk mengatasi masalah ini pemerintah memiliki strategi yaitu dengan memberikan perhatian besar terhadap pembangunan desa. Desa adalah bagian yang terpenting dalam segala proses pembangunan Bangsa dan Negara Indonesia, karena di setiap daerahdaerah di Indonesia terdiri dari desa-desa. Desa dijadikan sebagai tempat untuk menyelenggarakan dan memfasilitasi dalam segala hal yang dalam memenuhi kebutuhan masyarakat (Nafidah \& Suryaningtyas, 2015). Menurut Soerjono Soekanto (2006), Masyarakat adalah setiap kelompok manusia yang hidup, bekerja sama dan saling berinteraksi dalam suatu lingkungan yang sama dengan waktu yang relatif lama dan mampu membuat sebuah peraturan untuk dijadikan sebagai batasanbatasan dalam kehidupan bersama dan mereka menganggap sebagai satu kesatuan sosial (as cited in Dura, 2016).

Menurut Undang-undang Nomor 6 Tahun 2004, tentang desa menjelaskan bahwa desa pada tahun 2015 akan mendapatkan dana sebesar 10\% dari anggaran pendapatan dan belanja negara (APBN), dana yang didapatkan ini dinamakan dana desa. Berdasarkan peraturan pemerintah Nomor 8 tahun 2016 disebutkan bahwa dana desa adalah dana yang bersumber dari anggaran pendapatan dan belanja negara yang diperuntukan bagi desa yang ditransfer melalui anggaran pendapatan dan belanja daerah Kabupaten/ Kota dan digunakan untuk membiayai penyelenggaraan pemerintahan, pelaksanaan pembangunan, pembinaan kemasyarakatan, pemberdayaan dan kesejahteraan masyarakat (Fahri, 2017). Menurut Dura (2016), kebijakan pemerintah desa merupakan salah satu produk hokum karena setiap pemerintah desa secara hukumpun memiliki wewenang tersebut. Menurut Eko Putro Sandjojo (2017), Kementerian Desa, PDT dan Transmigrasi berupaya membuka informasi publik di level desa dengan memberikan informasi penyelenggaraan pembangunan desa dan nagari berikut dana yang dikelolanya untuk memastikan pengelolaan dana desa berjalan dengan baik maka perlu adanya kebijakan dari pemerintah desa mengenai pengawasan semua pihak yang tentunya harus didukung dengan keterbukaan informasi. Menurut Nasrul (2013), lembaga atau organisasi desa merupakan salah satu elemen penting dalam pembangunan desa. Tanpa adanya kelembagaan desa ini ditambah dengan adanya partisipan maka pembangunan infrastruktur tidak akan dapat dilakukan. Dengan diberlakukannya Peraturan Daerah Provinsi Sumatera Barat 2/2007 dimana dalam upaya melaksanakan tugas dan fungsi pemerintahan yang baik dan efektif di daerah, dimana partisipasi masyarakat dapat dikembangkan lebih luas, tidak terbatas sebagai pelaksana dan penerima manfaat dari program pengembangan masyarakat, tetapi secara aktif dapat terlibat langsung dalam proses pelaksanaan program-program pembangunan yang akan dilakukan.

Sebuah desa yang maju dapat dilihat dari tingkat kesejahteraan masyarakatnya, kesejahteraan masyarakat 
suatu desa dapat dilihat dari keadaan suatu desa tersebut, apabila pembangunan infrastruktur nya bagus maka masyarakatnya juga sejahtera karena masyarakat beserta lembaga desa juga berpartisipasi dalam memajukan desa. Oleh sebab itu pemerintah mengeluarkan kebijakan mengenai pembentukan Alokasi Dana Desa sebagai wujud dari desentralisasi keuangan menuju desa yang mandiri.

\section{Tinjauan Pustaka \\ Kesejahteraan Masyarakat}

Menurut Dura (2016), Kesejahteraan masyarakat adalah suatu tata cara dan penghidupan sosial, material dan spiritual yang diliputi oleh rasa keselamatan, kesusilaan dan ketentraman lahir batin yang meningkat bagi setiap warga Negara untuk mengadakan usaha pemenuhan kebutuhan jasmani, rohnai, dan social bagi diri, keluarga dan masyarakat. Kemudian, Karimah (2016) menyebutkan Kesejahteraan Sosial lembagalembaga, program-program, personel, dan kebijakankebijakan yang memusatkan pada pemberian pelayananpelayanan sosial kepada individu-individu, kelompokkelompok, dan masyarakat-masyarakat. Ilmu kesejahteraan sosial berupaya mengembangkan basis pengetahuannya untuk mengidentifikasi masalah sosial, penyebabnya dan strategi penanggulangannya. Selanjutnya, Rukminto (2005) mengungkapkan Kesejahteraan sosial adalah Suatu ilmu terapan yang mengkaji dan mengembangkan kerangka pemikiran serta metodelogi yang dapat dimanfaatkan untuk meningkatkan kualitas hidup (kondisi) masyarakat antara lain melalui pengelolaan masalah social, pemenuhan kebutuhan hidup masyarakat, dan pemaksimalan kesempatan anggota masyarakat untuk berkembang (Karimah, 2016). Kesejahteraan sosial adalah kondisi terpenuhinya kebutuhan material, spiritual, dan sosial warga Negara agar dapat hidup layak dan mampu mengembangkan diri, sehingga dapat melakukan fungsi sosialnya (Suharto, 2009, as cited in Karimah, 2016).

\section{Pelaporan Keuangan, Kebijakan Desa dan Kelembagaan Desa \\ Menurut Dura (2016), alokasi dana desa adalah} alokasi dana desa (ADD) merupakan dana yang dialokasikan oleh pemerintah Kabupaten untuk desa, yang bersumber dari bagian dana perimbangan keuangan pusat dan daerah yang diterima oleh Kabupaten. Untuk meningkatkan penyelenggaraan pemerintahan desa dalam melaksanakan pelayanan pemerintahan, pembangunan, dan kemasyarakatan sesuai kewenangannya. Kemudian, Lestari (2017) menyebutkan alokasi dana desa (ADD) adalah merupakan dana yang harus dialokasikan oleh Pemerintah Kabupaten untuk desa, yang bersumber dari bagian dana perimbangan keuangan pusat dan daerah yang diterima dari Kabupaten yang penggunaannya $30 \%$ untuk belanja aparatur dan operasional dan $70 \%$ untuk belanja publik dan pemberdayaan masyarakat. Selanjutnya, Mahfudz (2009) mengungkapkan Alokasi Dana Desa adalah program pembiayaan Pemerintahan Desa dalam melaksanakan kegiatan pemerintahan dan pemberdayaan masyarakat. Merupakan wujud dari pemenuhan hak desa untuk menyelenggarakan otonominya agar tumbuh dan berkembang mengikuti pertumbuhan dari desa itu sendiri berdasar keanekaragaman, partisipasi, otonomi asli, demokratisasi dan pemberdayaan masyarakat. Nugroho (2004) menuebutkan Implementasi kebijakan adalah langkah yang digunakan agar kebijakan tersebut dapat berjalan sesuai dengan rencana dalam mencapai tujuannya. Untuk mengimplementasikan kebijakan publik, maka ada dua pilihan langkah yang ada yaitu langsung mengimplementasikan dalam bentuk program- program atau melalui formulasi kebijakan derivat atau turunan dari kebijakan publik tersebut (Djumlani, 2014). Van Meter dan Van Horn (1975) menyebutkan Implementasi kebijakan adalah tindakan yang dilakukan baik oleh individu-individu atau pejabat-pejabat atau kelompokkelompok pemerintah atau swasta yang diarahkan pada tercapainya tujuan-tujuan yang telah digariskan dalam keputusan kebijaksanaan dan telah ditetapkan dalam keputusan-keputusan kebijakan sebelumnya (Djumlani, 2014).Kemudian, Grindle et al (1994) berpendapat Implementasi kebijakan adalah kepentingan kekuasaan, dan strategi aktor yang terlibat, karakteristik lembaga dan penguasan dan kepatuhan serta daya tanggap pelaksana, yang dipengaruhi oleh kebijakan, jenis manfaat yang akan dihasilkan, derajat perubahan yang digunakan, kedudukan pembuat kebijakan, siapa pelaksana program dan sumber daya yang dikerahkan. Membuat suatu hubungan yang memungkinkan tujuantujuan ataupun sasaran-sasaran kebijaksanaan negara dilaksanakan dan diwujudkan sebagai outcome (hasil akhir) kegiatan-kegiatan akhir yang diinginkan oleh pemerintah (Baharim, 2017).

Sandhi (2015) menyebutkan bahwa Lembaga kemasyarakatan adalah tempat mayarakat berpartisipasi dan menyalurkan aspirasinya dalam perencanaan, pelaksanaan dan pengendalian pembangunan yang bertumpu pada masyarakat. Dengan tujuan Untuk meningkatkan kemampuan masyarakat sebagai Sumber Daya Manusia (SDM) untuk mengolah dan memanfaatkan potensi Sumber Daya Alam (SDA) yang ada. Menurut Robert Mac Iver dan Charles H. Page dalam Soekanto (1990:218), Lembaga kemasyarakatan adalah tata cara atau prosedur yang telah diciptakan untuk mengatur hubungan antar-manusia yang berkelompok dalam suatu kelompok kemasyarakatan yang dinamakannya asosiasi. Untuk dapat membantu pemerintah desa dalam aspek perencanaan, pelaksanaan dan pengendalian pembangunan yang bertumpu pada 
masyarakat (Ampera, 2016). Senanda dengan hal ini, Emil Salim (1984) menyebutkan Lembaga Pemberdayaan Masyarakat yaitu lembaga yang digunakan untuk meningkatkan kemampuan masyarakat desa melalui pelaksanaan berbagai program pembangunan agar masyarakat dapat mencapai tingkat kemapanan yang diharapkan dan memberikan wewenang secara professional kepada masyarakat dalam pengambilan keputusan dalam rangka pembangunan diri (Purnama, 2017).

Penelitian yang dilakukan Dura (2016), yang meneliti pengaruh akuntabilitas pengelolaan keuangan Alokasi Dana Desa, kebijakan desa, dan kelembagaan desa terhadap kesejahteraan masyarakat pada Desa Gubuklakah Kecamatan Poncokusumo Kabupaten Malang. Hasil penelitian membuktikan bahwa akuntabilitas pengelolaan keuangan Alokasi Dana Desa, kebijakan desa, dan kelembagaan desa berpengaruh terhadap kebijakan desa, dan akuntabilitas pengelolaan keuangan Alokasi Dana Desa, kebijakan desa, dan kelembagaan desa berpengaruh secara bersama-sama terhadap kesejahteraan masyarakat. Romantis (2015), penelitian ini meneliti akuntabilitas Alokasi Dana Desa di Kecamatan Panarukan Kabupaten Situbondo. Hasil dari penelitian ini menunjukkan bahwa sistem akuntabilitasi perencanaan dan pelaksanaan telah menerapkan prinsip akuntabilitas dan transparan. Sedangkan, pertanggung jawaban Alokasi Dana Desa baik secara teknis maupun administrasi sudah baik, namun harus tetap mendapat atau diberikan bimbingan dari pemerintahan Kecamatan. Arifiyanto \& Kurrohman (2013), penelitian ini meneliti tentang akuntabilitas pengelolaan Alokasi Dana Desa di Kabupaten Jember. Hasil penelitian ini menunjukkan bahwa perencanaan dan pelaksanaan alokasi dan desa sudah menunjukan bahwa manajemen bertanggung jawab dan sudah menerapkan prinsip akuntabel dan transparan.

Dalam penelitian Dura (2016), Romantis (2015), Arifiyanto \& Kurrohman (2013) menjelaskan bahwa Akuntabilitas pengelolaan keuangan alokasi dana desa, kebijakan desa dan kelembagaan desa. Oleh sebab itu , hipotesis penelitian ini dapat disimpulkan bahwa:

H1 = Akuntabilitas Pengelolaan Keuangan Alokasi Dana Desa berpengaruh terhadap kesejahteraan masyarakat

$\mathrm{H} 2=$ Kebijakan Desa berpengaruh terhadap kesejahteraan masyarakat

$\mathrm{H} 3=$ Kelembagaan Desa berpengaruh terhadap kesejahteraan masyarakat

H4 = Akuntabilitas Pengelolaan Keuangan Alokasi Dana Desa, Kebijakan Desa dan Kelembagaan Desa berpengaruh terhadap Kesejahteraan Masyarakat

\section{Metode}

Jenis Penelitian yang digunakan pada penelitian ini adalah penelitian kuantitatif. Objek penelitian adalah suatu yang menjadi perhatian dalam suatu penelitian atau tempat / lokasi dimana seseorang meneliti sebuah riset. Pada penelitian ini yang menjadi objek penelitian adalah Nagari Sungai Tanang yang terletak di Kecamatan Banuhampu Kabupaten Agam. Populasi dalam penelitian ini adalah seluruh masyarakat yang ada di Nagari Sungai Tanang Kecamatan Banuhampu Kabupaten Agam yang berjumlah 528 Kepala Keluarga (KK) yang terdiri dari 3 jorong: Jorong Sungai Tanang Gadang $=268$ KK; Jorong Sungai Tanang Ketek $=146$ KK; Jorong Pandan Gadang $=114$ KK. Pengambilan sampel dalam penelitian ini dilakukan dengan menggunakan Stratified Random Sampling, yaitu populasi yang dianggap heterogen menurut suatu karakteristik tertentu dikelompokkan terlebih dahulu dalam sub populasi sehingga tiap sub populasi yang ada memiliki anggota sampel yang relatif homogen. Pengambilan sampel yang dibutuhkan dalam penelitian ini yaitu dengan menggunakan rumus solvin. Metode slovin pada penelitian ini di gambarkan pada rumus dibawah ini :

$$
\begin{aligned}
& \mathrm{n}=\frac{N}{1+N e^{2}} \\
& \mathrm{n}=\frac{528}{1+528(0,05)^{2}}=228
\end{aligned}
$$

Sampel yang akan adalah 228 sampel. Maka dari ketiga jorong tersebut diambil masing-masing 76 sampel. Adapun jenis dan sumber data yang digunakan adalah data primer dan data sekunder. Data primer dilakukan dengan penyebaran kuesioner yang disebarkan kepada masyarakat di Nagari Sungai Tanang. Selanjutnya kuesioner diberikan bobot sesuai dengan tingkat kepentingan model skala Likert dengan bobot 15. Data sekunder pada penelitian ini yaitu berupa struktur bagan struktur pengurus BAMUS Nagari Sungai Tanang dan bagan susunan organisasi pemerintah nagari Periode 2017-2022. Teknik pengumpulan data yaitu dengan melakukan penyebaran kuesioner yang terdiri dari 10 item pernyataan Y (kesejahteraan masyarakat), 3 item pernyataan $\mathrm{X} 1$ (Akuntabilitas pengelolaan keuangan alokasi dana desa), 8 item pernyataan X2 (kebijakan desa) dan 7 item pernyataan untuk X3 (kelembagaan desa) dan juga dengan menggunakan studi kepustakaan. Analisis data menggunakan metode data yang digunakan dengan regresi linear berganda menggunakan SPSS 23 for windows. Tahapan dalam analisis data dimulai dari uji validitas dan realibilitas terhadap jawaban yang diberikan oleh responden dalam kuesioner. Selanjutnya dilakukan uji asumsi klasik (uji normalitas, uji multikolinearitas dan uji heteroskedastisitas) untuk menyimpulkan persamaan regresi berganda pada penelitian ini. Kemudian dilakukan pengujian hipotesis yang terdiri dari uji f, uji t dan koefisien determinasi. Defenisi operasional variabel secara garis besar, dalam penelitian ini terdapat dua variabel, yaitu variabel terikat (Dependent Variable) dan variabel bebas (Independent Variable). Menurut (Nugroho, Handayani, \& Saifi, 2014) variabel terikat 
adalah Variabel terikat merupakan variabel yang dipengaruhi atau yang menjadi akibat, karena adanya variabel bebas. Dalam penelitian ini variabel terikatnya adalah kesejahteraan masyarakat (Y). Sedangkan, Variabel bebas adalah merupakan variabel yang mempengaruhi atau yang menjadi sebab perubahannya atau timbulnya variabel dependen (terikat). Dalam penelitian ini adalah Akuntabilitas pengelolaan keuangan alokasi dana desa $\left(\mathrm{X}_{1}\right)$, kebijakan desa $\left(\mathrm{X}_{2}\right)$ dan kelembagaan desa $\left(\mathrm{X}_{3}\right)$.

Hasil

Berdasarkan pengujian statistik yang telah dilakukan diperoleh ringkasan hasil pengolahan data secara deskriptif yang terlihat pada tabel dibawah ini:

Tabel 1

Descriptive Statistics

\begin{tabular}{|l|r|r|r|r|r|}
\hline & \multicolumn{1}{|c|}{ N } & \multicolumn{1}{|c|}{ Minimum } & Maximum & \multicolumn{1}{c|}{ Mean } & \multicolumn{1}{c|}{ Std. Deviation } \\
\hline $\mathrm{Y}$ & 103 & 27 & 48 & 40.88 & 3.476 \\
\hline $\mathrm{X} 1$ & 103 & 2 & 10 & 7.88 & 1.838 \\
\hline $\mathrm{X} 2$ & 103 & 21 & 39 & 32.02 & 3.799 \\
\hline $\mathrm{X} 3$ & 103 & 17 & 33 & 28.80 & 2.991 \\
\hline Valid N (listwise) & 103 & & & & \\
\hline
\end{tabular}

Sumber: Hasil Olahan

Berdasarkan tabel diatas terlihat bahwa variabel penelitian yang digunakan di dalam penelitian ini adalah kesejahteraan masyarakat degan menggunakan istilah Y, akuntabilitas pengelolaan keuangan alokasi dana desa dengan istilah $\mathrm{X} 1$, kebijakan desa dengan istilah $\mathrm{X} 2$ dan kelembagaan desa dengan istilah X3. Total data yang digunakan berjumlah 103 data. Secara keseluruhan tingkat kesejahteraan masyarakat terendah adalah sebesar 27, tingkat kesejahteraan masyarakat (Y) tertinggi 48 , tingkat rata-rata 40,88 dengan standar deviasi 3,476. Selanjutnya tingkat akuntabilitas pengelolaan keuangan alokasi dana desa (X1) terendah adalah sebesar 2, tingkat akuntabilitas pengelolaan keuangan alokasi dana desa (X1) tertinggi 10, tingkat rata-rata sebesar 7,88 dengan standar deviasi 1,838. Selanjutnya tingkat kebijakan desa (X2) terndah adalah sebesar 21, tingkat kebijakan desa tertinggi sebesar 39, tingkat rata-rata 32,02 dengan tstandar deviasi 3,799 dan yang terakhir yaitu tingkat kelembagaan desa (X3) terendah adalah sebesar 17, tingkat kelembagaan desa tertinggi adalah sebesar 33, tingkat rata-rata 28,80 dengan standar deviasi 2,991.

\section{Uji Reliabilitas}

Tabel 2

Hasil Uji Reliabilitas

\begin{tabular}{|l|l|r|r|}
\hline No & \multicolumn{1}{|c|}{ Variabel } & Cronbach's Alpha & Keterangan \\
\hline 1. & Akuntabilitas Pengelolaan Keuangan Alokasi Dana Desa & 0.779 & Realibel \\
\hline 2. & Kebijakan Desa & 0.773 & Realibel \\
\hline 3. & Kelembagaan Desa & 0.731 & Realibel \\
\hline 4. & Kesejahteraan Masyarakat & 0.713 & Realibel \\
\hline
\end{tabular}

Sumber: Hasil Olahan

Ttabel 2 menjelaskan dapat diambil kesimpulan bahwa dari uji reliabilitas dihasilkan nilai Cronbach's Alpha untuk variabel penelitian akuntabiltas pengelolaan keuangan alokasi dana desa, kebijakan desa, kelembagaan desa dan kesejahteraan masyarakat lebih besar dari 0,70 yaitu untuk variabel akuntabilitas pengelolaan keuangan alokasi dana desa dimana nilai Cronbach's Alpha 0.779 yang berada pada kategori sangat tinggi, untuk variabel kebijakan desa Cronbach's Alpha 0.773 sedangkan kelembagaan desa Cronbach's Alpha 0,731 dan untuk kesejahteraan masyarakat Cronbach's Alpha 0.713 yang secara keseluruhan memberikan hasil bahwa variabel yang diteliti memenuhi syarat untuk konsistensi. Jadi item-item pertanyaan untuk variabel tersebut dapat dipakai sebagai alat ukur dalam penelitian.

\section{Uji Validitas}

Jumlah responden sebanyak 103 maka nilai $r$ tabel dapat diperoleh melalui tabel $r$ product moment pearson dengan $\mathrm{df}$ (degree of freedom $)=\mathrm{n}-2$, jadi $\mathrm{df}=$ $103-2=101$, maka $r$ tabel $=0,194$. Butir pernyataan nya dikatakan valid apabila nilai $r$ hitung $>r$ tabel. Hasil uji validitas variabel penelitian adalah sebagai berikut: 
Lasmi Yupita dan Verni Juita, Pengaruh Akuntabilitas Pengelolaan Keuangan Alokasi Dana Desa, Kebijakan Desa Dan Kelembagaan Desa Terhadap Kesejahteraan Masyarakat Pada Nagari Sungai Tanang Kecamatan Banuhampu Kabupaten Agam

Tabel 3

Hasil Uji Validitas Variabel

\begin{tabular}{|c|c|c|c|c|}
\hline Variabel & Item Kuesioner & R Tabel & Cronbach's Alpha & Keterangan \\
\hline \multirow{3}{*}{$\begin{array}{l}\text { Akuntabilitas Pengelolaan } \\
\text { Alokasi Dana Desa }\end{array}$} & Item 1 & 0,194 & 0.790 & Valid \\
\hline & Item 2 & 0,194 . & 0.768 & Valid \\
\hline & Item 3 & 0,194 . & 0.778 & Valid \\
\hline \multirow[t]{8}{*}{ Kebijakan Desa } & Item 1 & 0,194 . & .741 & Valid \\
\hline & Item 2 & 0,194 . & .759 & Valid \\
\hline & Item 3 & 0,194 . & .739 & Valid \\
\hline & Item 4 & 0,194 . & .760 & Valid \\
\hline & Item 5 & 0,194 & .748 & Valid \\
\hline & Item 6 & 0,194 . & .760 & Valid \\
\hline & Item 7 & 0,194 . & .750 & Valid \\
\hline & Item 8 & 0,194 . & .733 & Valid \\
\hline \multirow[t]{7}{*}{ Kelembagaan Desa } & Item 1 & 0,194 . & .700 & Valid \\
\hline & Item 2 & 0,194 . & .724 & Valid \\
\hline & Item 3 & 0,194 . & .689 & Valid \\
\hline & Item 4 & 0,194 . & .682 & Valid \\
\hline & Item 5 & $0,194$. & .675 & Valid \\
\hline & Item 6 & 0,194 . & .701 & Valid \\
\hline & Item 7 & 0,194 . & .719 & Valid \\
\hline \multirow[t]{10}{*}{ Kesejahteraan Masyarakat } & Item 1 & 0,194 . & .684 & Valid \\
\hline & Item 2 & 0,194 . & .700 & Valid \\
\hline & Item 3 & 0,194 . & .689 & Valid \\
\hline & Item 4 & 0,194 . & .693 & Valid \\
\hline & Item 5 & 0,194 . & .690 & Valid \\
\hline & Item 6 & 0,194 . & .695 & Valid \\
\hline & Item 7 & $0,194$. & .668 & Valid \\
\hline & Item 8 & 0,194 . & .699 & Valid \\
\hline & Item 9 & $0,194$. & .694 & Valid \\
\hline & Item 10 & 0,194 . & .694 & Valid \\
\hline
\end{tabular}

Sumber: Hasil Olahan

Tabel 3 diatas maka dapat ditarik kesimpulan bahwa dari seluruh item pernyataan variabel dikatakan valid karena Corrected Item-Total Correlation dari pernyataan tersebut $r$ hitung $>r$ tabel sehingga dapat digunakan untuk penelitian lebih lanjut.

\section{Uji Asumsi Klasik}

Uji Normalitas
Uji normalitas bertujuan untuk menguji apakah dalam model regresi variabel pengganggu atau residual memiliki distribusi normal. Pengujian normalitas dapat dilakukan dengan menggunakan Kolmogorov smirnov (Ks) dengan dan melihat Probability plot titik penyebaran indikator variabel independen terhadap variabel dependen. Hasil uji normalitas data terdapat pada tabel di berikut ini:

Tabel 4

Hasil Uji Normalitas

\begin{tabular}{|l|r|r|}
\hline & \multicolumn{2}{|c|}{ Standardized Residual } \\
\hline \multirow{2}{*}{ Normal Parameters ${ }^{\mathrm{a}, \mathrm{b}}$} & & \multicolumn{2}{|c|}{ Mean } & 103 \\
\hline \multirow{2}{*}{ Most Extreme Differences } & Std. Deviation & .0000000 \\
\cline { 2 - 3 } & Absolute & .98518437 \\
\cline { 2 - 4 } & Positive & .082 \\
\cline { 2 - 4 } & Negative & .082 \\
\hline Kolmogorov-Smirnov Z & & -.069 \\
\hline Asymp. Sig. (2-tailed) & & .837 \\
\hline
\end{tabular}

Sumber: Hasil Olahan 
Perbandingan nilai signifikasi yang dihasilkan > 0.05 maka distribusi datanya dikatakan normal, sebaliknya jika signifikasi yang dihasilkan $<0.05$ maka data tidak terdistribusi secara normal. Sedangkan untuk p-plot penyebaran indikator hendaknya mendekati garis potong. Dari tabel diatas terlihat bahwa hasil uji normalitas menunjukkan bahwa nilai signifikansi pengujian Kolmogorov-Smirnov sebesar 0,486 > 0,05 berdistribusi normal maka data tersebut dapat digunakan untuk penelitian lebih lanjut.

\section{Uji Multikolinearitas}

Uji multikorelasi bertujuan untuk melihat korelasi antar variabel indenpenden (X). Apabila terdapat multikolinearitas yang signifikan antar sesama variabel indenpenden maka harus dieliminasi dari analisis regresi berganda. Uji multikoloniearitas dapat diuji dengan nilai VIF untuk masing-masing variabel indenpenden. Persyaratan untuk bebas dari multikolinearitas adalah apabila angka tolerance $>0,10$ dan VIF $<10$ maka dikatakan tidak terdapat gejala multikoloniearitas, sedangkan jika tolerance $<0,1$ dan VIF > 10 berarti terjadi multikolinearitas . Hasil ini sesuai dengan pengujian multikolinearitas yang terdapat pada tabel berikut:

Tabel 5

Hasil Uji Multikolinearitas

\begin{tabular}{|l|l|r|r|}
\hline \multirow{2}{*}{ Model } & \multicolumn{2}{|c|}{ Collinearity Statistics } \\
\cline { 3 - 5 } & APKADD & Tolerance & VIF \\
\cline { 2 - 5 } & KBD & 1.000 & 1.000 \\
\cline { 2 - 5 } & KLD & .826 & 1.211 \\
\hline
\end{tabular}

Sumber: Hasil Olahan

Berdasarkan Tabel 5 diatas dapat diketahui bahwa nilai tolerance variabel independen sebesar 1,000 (akuntabilitas pengelolaan keuangan alokasi dana desa), 0,826 (kebijakan desa), 0,826 (kelembagaan desa) berada diatas standar tolerance 0,10 sedangkan nilai VIF semua variabel indenpendennya lebih kecil dari 10, yaitu 1,000 (akuntabilitas pengelolaan keuangan alokasi dana desa), 1,211 (kebuijakan desa), 1,211 (kelembagaan desa). Hal ini berarti bahwa hasil analisis menunjukan tidak ada terdapatnya gejala multikoloniearitas sehingga pengujian layak menggunakan model regresi berganda.

\section{Uji Heteroskedastisitas}

Uji heteroskedastisitas digunakan untuk melihat apakah dalam sebuah model regresi terjadi ketidaksamaan varians dari residual atas suatu pengamatan kepengamatan lain. Jika varians dari residual suatu pengamatan ke pengamatan lain tetap, maka disebut homokedastisitas dan jika berbeda disebut heterokedastisitas. Untuk mendeteksi adanya gejala heterokedastisitas dilakukan uji Glejser dan melihat Scatterplot penyebaran titik yang tidak membentuk pola tertentu. Apabila signifikan probabilitasnya $>0,05$ atau $5 \%$ maka tidak terjadi heteroskedastisitas tetapi jika tingkat signifikan probabilitasnya $<0,05$ atau 5\% maka terjadi heteroskedastisitas. Hasil pengujian dapat dilihat pada tabel dibawah ini:

Tabel 6

Hasil Uji Heteroskedastisitas

\begin{tabular}{|l|l|r|r|}
\hline \multicolumn{1}{|c|}{ Model } & $\mathrm{t}$ & \multicolumn{1}{c|}{ Sig. } \\
\hline \multirow{3}{*}{1} & (Constant) & 3.694 & .000 \\
\cline { 2 - 5 } & APKADD & -1.164 & .247 \\
\cline { 2 - 5 } & KBD & -1.251 & .214 \\
\cline { 2 - 5 } & KLD & -1.408 & .162 \\
\hline
\end{tabular}

Sumber: Hasil Olahan

Tabel 6 diatas dapat diketahui bahwa nilai probabilitas signifikansi variabel independen sebesar 0,247 (akuntabilitas pengelolaan keuangan alokasi dana desa), 0,214 (kebijakan desa) dan 0,162 (kelembagaan desa) berada diatas tingkat nilai kepercayaan sebesar
5\%. Jadi dapat disimpulkan model regresi ini tidak mengandung adanya gejala heteroskedastisitas.

F test 
Lasmi Yupita dan Verni Juita, Pengaruh Akuntabilitas Pengelolaan Keuangan Alokasi Dana Desa, Kebijakan Desa Dan Kelembagaan Desa Terhadap Kesejahteraan Masyarakat Pada Nagari Sungai Tanang Kecamatan Banuhampu Kabupaten Agam

Tabel 7

Hasil Uji F

\begin{tabular}{|l|r|r|r|r|r|}
\hline \multicolumn{1}{|c|}{ Model } & \multicolumn{1}{c|}{ Sum of Squares } & \multicolumn{1}{c|}{ Df } & Mean Square & \multicolumn{1}{c|}{ F } & \multicolumn{1}{c|}{ Sig. } \\
\hline Regression & 586.092 & 3 & 195.364 & 29.916 & $.000^{\mathrm{a}}$ \\
\hline Residual & 646.510 & 99 & 6.530 & & \\
\hline Total & 1232.602 & 102 & & & \\
\hline
\end{tabular}

Sumber: Hasil Olahan

Berdasarkan dari hasil pengujian pada tabel dapat dilihat pada nilai signifikansi hipotesis secara simultan adalah 0,000 , hal ini menunjukkan bahwa nilai signifikansi lebih kecil dari 0,05 maka berarti terdapat pengaruh yang signifikansi secara bersama-sama antara akuntabilitas pengelolaan keuangan alokasi dana desa (X1), kebijakan desa (X2) dan kelembagaan desa (X3) terhadap kesejahteraan masyarakat (Y) di Nagari Sungai tanang. Tingkat signifikansi yang digunakan dalam pengujuian adalah $\alpha=0,05$, derajat kebebasan ialah df1 ( Jumlah variabel -1 ) $=4-1=3$ dan df2 (jumlah sampel - jumlah variabel $)=103-3=100$. Setelah melihat tabel F, maka hasil yang diperoleh untuk $\mathrm{f}$ tabel adalah sebesar 2,70. Jika dibandingkan nilai antara $f$ hitung dengan $\mathrm{f}$ tabel maka $\mathrm{f}$ hitung $>\mathrm{f}$ tabel yaitu 29,916> 2,70, maka H4 diterima. Jadi dapat disimpulkan bahwa akuntabilitas pengelolaan keuangan alokasi dana desa, kebijakan desa dan kelembagaan desa secara bersama-sama (simultan) memiliki pengaruh yang signifikan terhadap kesejahteraan masyarakat di Nagari Sungai tanang.

\section{Uji Koefisien Determinasi}

Tabel 8

Hasil Uji Koefisien Determinasi

\begin{tabular}{|c|c|c|c|c|}
\hline & & & & \\
\hline Model & $\mathrm{R}$ & R Square & Adjusted R Square & Std. Error of the Estimate \\
\hline 1 & $.690^{\mathrm{a}}$ & .475 & .460 & 2.555 \\
\hline
\end{tabular}

Sumber: Hasil Olahan

Berdasarkan tabel di atas, dapat diketahui nilai $R$ square - nya sebesar 0,460. Hal ini menunjukkan bahwa akuntabilitas pengelolaan keuangan alokasi dana desa, kebijakan desa dan kelembagaan desa memberikan kontribusi terhadap kesejahteraan masyarakat sebesar
46,0\%. Sedangkan sisanya di sumbangkan oleh faktorfaktor lain yang tidak diteliti dalam penelitian ini.

\section{Uji Regresi Linear Berganda}

Tabel 9

Hasil Uji Regresi Linear Berganda

\begin{tabular}{|c|c|c|c|c|c|}
\hline \multirow[b]{2}{*}{ Model } & \multicolumn{2}{|c|}{ Unstandardized Coefficients } & \multirow{2}{*}{$\frac{\text { Standardized Coefficients }}{\text { Beta }}$} & \multirow[b]{2}{*}{$\mathrm{t}$} & \multirow[b]{2}{*}{ Sig. } \\
\hline & $\mathrm{B}$ & Std. Error & & & \\
\hline (Constant) & 14.302 & 2.961 & & 4.830 & .000 \\
\hline APKADD & .283 & .138 & .14 & 2.052 & .043 \\
\hline KBD & .461 & .073 & .50 & 6.285 & .000 \\
\hline KLD & .334 & .093 & .28 & 3.584 & .001 \\
\hline
\end{tabular}

Sumber: Hasil Olahan

Berdasarkan tabel diatas diantara keempat variabel independen dari akuntabilitas pengelolaan keuangan alokasi dana desa, kebijakan desa dan kelembagaan desa tersebut signifikan atau tidak terhadap kesejahteraan masyarakat yang dikemukakan pada tabel Acuan yang digunakan adalah jika $t$ hitung $>t$ tabel atau nilai sig < 0,05 maka $\mathrm{H} 0$ ditolak dan Ha diterima, tetapi sebaliknya jika $t$ hitung $<\mathrm{t}$ tabel atau nilai sig $>0,05$ maka $\mathrm{H} 0$ diterima dan $\mathrm{Ha}$ ditolak. Dengan tingkat signifikasi menggunakan $\alpha=0,05$ dan derajat kebebasan $(\mathrm{df})=$ jumlah sampel $-3=103-3=100$. Dengan merujuk pada tabel $\mathrm{t}$, maka diperoleh hasil $\mathrm{t}$ tabel yaitu sebesar 1,66023. variabel akuntabilitas pengelolaan keuangan alokasi dana desa berpengaruh signifikan terhadap kesejahteraan masyarakat di Nagari Sungai tanang, hal ini terlihat dari nilai signifikannya yaitu $0,034<0,05$. Dan nilai $\mathrm{t}$ hitung $>\mathrm{t}$ tabel yaitu $2.147>1,66023$ artinya, jika ditingkatkan variabel akuntabilitas pengelolaan keuangan alokasi dana desa sebesar satu satuan maka tingkat kesejahteraan masyarakat akan bertambah sebesar 0,196. Dengan demikian hipotesis pertama (H1) "akuntabilitas pengelolaan keuangan alokasi dana desa berpengaruh secara signifikan terhadap kesejahteraan masyarakat" dapat diterima. Sementara itu hasil uji yang sama yaitu secara parsial (uji T), variabel kebijakan desa juga 
berpengaruh signifikan terhadap kesejahteraan masyarakat di Nagari Sungai tanang, hal ini terlihat dari nilai signifikannya yaitu $0.000<0.05$. dan nilai t hitung $>$ t tabel yaitu $6.317>1,66023$ artinya jika ditingkatkan variabel kebijakan desa sebesar satu satuan, maka kesejahteraan masyarakat akan meningkat sebesar 0,462. Dengan demikian hipotesis kedua (H2) " kebijakan desa berpengaruh secara signifikan terhadap kesejahteraan masyarakat" dapat diterima. Sementara itu dari hasil uji yang sama secara parsial (uji T), variabel kelembagaan desa juga berpengaruh secara signifikan terhadap kesejahteraan masyarakat di Nagari Sungai tanang, hal ini dapat dilihat dari nilai signifikannya yaitu $0,001<$ 0,05 . Dan nilai $t$ hitung $>\mathrm{t}$ tabel yaitu $3.567>1,66023$ artinya, jika ditingkatkan variabel kelembagaan desa satu satuan maka kesejahteraan masyarakat akan meningkat sebesar 0,331". Dengan demikian hipotesis ketiga (H3) "kelembagaan desa berpengaruh signifikan terhadap kesejahteraan masyaarakat" dapat diterima.

\section{Simpulan}

Berdasarkan hasil penelitian yang diperoleh pada bab sebelumnya dapat disimpulkan bahwa, objek penelitian pada penelitian ini adalah Nagari Sungai Tanang. Data penelitian yang digunakan pada penelitian ini berupa penyebaran kuesioner kepada masyarakat yang berada di Nagari Sungai tanang. Semua data diolah menggunakan analisis regresi berganda dengan melihat uji validitas, realibiltas, dan pengujian hipotesis dengan uji $\mathrm{F}$ dan uji $\mathrm{T}$. Variabel pada penelitian ini yaitu akuntabilitas pengelolaan keuangan alokasi dana desa, kebijakan desa, kelembagaan desa dan kesejahteraan masyarakat. Dengan hasil, akuntabilitas pengelolaan keuangan alokasi dana desa berpengaruh positif terhadap kesejahteraan masyarakat di Nagari Sungai tanang (H1). Kebijakan desa berpengaruh positif terhadap kesejahteraan masyarakat di Nagari Sungai tanang (H2). Kelembagaan desa berpengaruh positif terhadap kesejahteraan masyarakat di Nagari Sungai tanang (H3), dan akuntabilitas pengelolaan keuangan alokasi dana desa, kebijakan desa dan kelembagaan desa berpengaruh positif terhadap kesejahteraan masyarakat di Nagari Sungai tanang (H4).

\section{Daftar Pustaka}

www.agamkab.go.id. Retrieved September 9, 2016,

Ampera. 2016. Perilaku Kepemimpinan Kepala Desa dalam Lembaga Formal Desa terhadap Peran Anggota Lembaga Formal Desa. Bogor: Skripsi Institut Pertanian Bogor.

Arifiyanto, D. F., Kurrohman, dan T. 2013. Akuntabilitas Pengelolaan Alokasi Dana Desa Di Kabupaten Jember. Jurnal Riset Akuntansi dan Keuangan vol 2 No 3, hal: 481-493.

Azwardi, Sukanto. 2014. Efektifitas Alokasi Dana Desa (ADD) dan Kemiskinan di Provinsi Sumatera
Selatan. Jurnal Ekonomi Pembangunan vol 12, No.1, hal: 29-41.

Baharim, S. 2017. "Studi Implementasi Kebijakan Alokasi Dana Desa Dan Dana Desa Di Desa Bungi Kecamatan Kontunaga Kabupaten Muna". Kendari: Skripsi Universitas Halu Oleo.

Djumlani, A. 2014. Implementasi Kebijakan Alokasi Dana Desa ( ADD ) Di Desa Balansiku Kecmatan Sebatik. Journal Administrative Reform vol 2 No.3 hal: 1732-1745.

Dura, J. 2016. Pengaruh Akuntabilitas Pengelolaan Keuangan Alokasi Dana Desa, Kebijakan Desa dan Kelembagaan Desa terhadap Kesejahteraan Masyarakat (Studi Kasus Pada Desa Gubugklakah Kecamatan Poncokusumo Kabupaten Malang). Jurnal JIBEKA vol 10, No.1 hal: 26-32.

Fahri, L. N. 2017. Pengaruh Pelaksanaan Kebijakan Dana Desa terhadap Manajemen Keuangan Desa dalam Meningkatkan Efektivitas Program Pembangunan Desa. Jurnal Ilmiah Bidang Ilmu Administrasi vol 11, No.1 hal:75-88.

Ghozali, I. 2014. Aplikasi Analisis Multivariate dengan Program IBM SPSS 20. Semarang: Badan Penerbit Universitas Diponegoro.

Huri, R. V. 2015. Akuntabilitas Pengelolaan dan Pemanfaatan Alokasi Dana Desa ( ADD ) dalam Proses Pembangunan di Desa Dasri Kecamatan Tegal sari Kecamatan Banyuwangi tahun 2013. Jember: Skripsi Universitas Jember.

Karimah, C. 2016. Upaya Badan Keswadayaan Masyarakat (BKM) dalam Pemberdayaan Masyarakat. Semarang: Fakultas Matematika dan Ilmu Pengetahuan Alam Universitas Semarang.

Kila, K. K. 2017. Pengelolaan Alokasi Dana Desa Dalam Meningkatkan Pemberdayaan Masyarakat Di Desa Miau Baru Kecamatan Kongbeng, Jurnal Administrasi Negara vol 5 No.1 hal: 5188-5200.

Kindran, G. 2014. Upaya Badan Keswadayaan Masyarakat (BKM) dalam Pemberdayaan Masyarakat. Jurnal Administrasi Publik vol 1. No. 10 hal:35-40.

Lestari, S. 2017. Analisis Akuntabilitas Pengelolaan Alokasi Dana Desa (ADD) (Studi Kasus di Wilayah Kecamatan Banyudono). Jawa Tengah: Skripsi IAIN Surakarta.

Mahfudz. 2009. Analisis Dampak Alokasi Dana Desa (ADD) Terhadap Pemberdayaan Masyarakat Dan Kelembagaan Desa. Jurnal Organisasi dan Manajemen. Vol 5. No 1 hal: 10-22.

Nafidah, L. N., Suryaningtyas, M. 2015. Akuntabilitas Pengelolaan Alokasi Dana Desa Dalam Upaya Meningkatkan Pembangunan dan Pemberdayaan Masyarakat. Jurnal Bisnis dan Manajemen Islam 
Vol 3, No 1 .

Nasrul, W. 2013. Peran kelembagaan lokal adat dalam pembangunan desa. vol 14. hal: 102-109.

Nugroho, D. A. D., Handayani, S. R., Saifi, M. 2014. Pengaruh Drop Box dan E-Filling terhadap Kepatuhan Penyampaian SPT Tahunan PPh. Malang: Skripsi Universitas Negeri Islam Maulana Malik Ibrahim.

Purnama, O. 2017. Peran Lembaga Pemberdayaan Masyarakat (LPM) Pekon Gadingrejo Timur Kecamatan Gading Rejo Kabupaten Pringsewu Dalam Penyusunan Rencana Pembangunan Jangka Menengah Peko. Bandar Lampung: Skripsi Universitas Lampung.

Riyanto, T. 2015. Akuntabilitas Finansial Dalam Pengelolaan Alokasi Dana Desa (ADD) di Kantor Desa Perangat Selatan Kecamatan Marangkayu Kabupaten Kutai Kartanegara. Jurnal Administrasi Negara vol 3. No 1 hal:119130.

Romantis, P. A. 2015. Akuntabilitas Pengelolaan Alokasi Dana Desa di Kecamatan Panarukan Kabupaten Situbondo Tahun 2014. Jember: Skripsi Fakultas Ekonomi.

Sandhi, R. hargita. 2015. Partisipasi Lembaga Pemberdayaan Masyarakat Desa Dalam Perencanaan Pembangunan Desa (Studi Kasus di Desa Karangwuni Kecamatan Rongkop). Yogyakarta: Skripsi Fakultas Ilmu Pendidikan Universitas Yogyakarta.

Sarifudin, S. 2012. Budaya Kepeloporan Masyarakat Torosiaje Pasca Reformasi. Gorontalo: Skripsi Universitas Gorontalo.

Setiawan, A. P. 2014. Pengaruh Penereapan Pengendalian Intetrnal dan Kompetensi Staf Akuntansi terhadap kualitas laporan Keuangan. Bandung: Skripsi Universitas Pasundan.

Sugiarto, E., Salmani, Gunawan., bambang indratno. 2007. Studi Tingkat Kesejahteraan Masyarakat Nelayan di Kampung Gurimbang Kecamatan Sambaliung Kabupaten Berau. Samarinda: Universitas Mulawarman.

Sugiyono. (2011). Metode Penelitian Kuantitatif, Kualitatif dan $R \& D$. Bandung: Alfabeta.

Sujarweni, V. W. 2016. Kupas Tuntas Penelitian Akuntansi dengan SPSS. Yogyakarta: Pustaka Baru Press.

Suryani, \& Hendryadi. 2015. Metode Riset Kuantitatif. Jakarta: Prenadamedia Group.

Tuwaidan, M. 2013. Implementasi Kebijakan Alokasi Dana Desa Di Desa Watudambo Kecamatan Kauditan Kabupaten Minahasa Utara. Minahasa: Jurnal Akuntansi.

Wida, S. A. 2016. Akuntabilitas Pengelolaan Alokasi Dana Desa ( ADD ) Di Desa - Desa Kecamatan Rogojampi. Jember: Fakultas Ekonomi 